引用格式:杨国永, 江强, 田甜, 等. 农民工回乡建房的家庭福利效应: 基于福建省农民工流出地的调查[J]. 资源科学, 2019, 41 (7): 1213-1226. [Yang G Y, Jiang Q, Tian T, et al. Household welfare change of migrant workers returning home to build houses: Based on a survey of migrant worker source areas in Fujian Province[J]. Resources Science, 2019, 41(7): 1213- 1226.] DOI: 10.18402/resci.2019.07.03

\title{
农民工回乡建房的家庭福利效应 一一基于福建省农民工流出地的调查
}

\author{
杨国永 ${ }^{1}$, 江 强 ${ }^{2}$, 田 甜 ${ }^{1}$, 许文兴 ${ }^{3}$ \\ (1. 福建农林大学公共管理学院,福州 $350002 ; 2$. 福建农林大学计算机与信息学院,福州 350002 ; \\ 3. 福建农林大学管理学院, 福州 350002)
}

\begin{abstract}
摘 要: 居住是福利的重要组成部分,也是其他福利保障的基础。本文基于阿玛蒂亚・森的可行能力理论,构 建回乡建房农民工福利评价指标体系; 采用模糊数学综合评价方法,利用在福建省农民工流出地的问卷调查数据, 评价农民工回乡建房的家庭福利效应; 借鉴洛伦兹系数的计算方法, 比较不同农民工回乡建房前后家庭福利差 异。研究发现: 回乡建房对农民工家庭福利有正向的促进作用, 并在一定程度上缩小了建房家庭之间的福利差异; 但农民工家庭福利仍然低于中等水平, 其中家庭经济方面的福利变差。基于提高农民工家庭福利的目标要求, 应 推进农民工就地城镇化, 提高实际居住福利; 加强对农民工回乡建房引导与管理, 倡导合理适度的住房建设, 减轻 因建房所造成的经济负担; 盘活闲置宅基地和住房资源, 增加农民工的财产性收入。比较建房前后福利变化可以 较好地研判回乡建房对农民工家庭的影响, 并有助于深化对此现象的理解, 为政府制定政策提供依据。
\end{abstract}

关键词:农民工;回乡建房;福利; 可行能力;模糊数学;洛伦兹系数;福建省

DOI :10.18402/resci.2019.07.03

\section{1 引言}

在“居者有其屋”传统观念的影响下,住房与农 民工的安全感、认同感、幸福感等存在广泛而深刻 的联系 ${ }^{[1]}$ 。近年来, 直于城市住房价高而不得, 部分 农民工选择回乡建房, 并普遍扩大了住房面积, 住 房质量也有了较大提升, 家人的居住福利获得一定 改善。但还有相当部分农民工在建房之后继续外 出, 甚至举家迁移, 并且也预期未来可能不会回乡 定居, 通过出租实现其资产价值的非常少 ${ }^{[2]}$, 增值获 利的可能性也很小。但即便如此, 近年仍然有相当 比例的农民工选择回乡建房。明娟等 ${ }^{[3]}$ 的调查发 现 , 45.38\%农民工已在家乡投资住房。对此现象， 显然不能仅从经济效应层面去理解, 需要从更为综
合的视角进行解释。无疑, 福利是比较适合的分析 角度, 可以从经济、社会、心理等方面综合分析回乡 建房为农民工家庭所带来的变化。毕竟福利是评 价人类生活品质和幸福程度的重要指标 ${ }^{[4]}$, 福利改 善是人们行为选择的重要目标之一。因此,采用建 房前后福利对比可以较好地研判回乡建房对农民 工家庭的影响, 并深化对此现象的理解, 为政府制 定政策提供依据。

综观国内外研究, 国外研究中没有农民工回乡 建房的议题, 与本研究相关的研究领域是国际移民 回母国的原籍社区建造住房。二者可以统归在“移 民回乡建房” 这一主题中, 能为本研究提供参考借 鉴 ${ }^{[5]}$ 。对于移民回乡建房的影响, 国外研究并不

收稿日期: 2018-10-22, 修订日期: 2019-04-17

基金项目:国家社会科学基金项目(17BFX085);福建农林大学科技创新专项基金项目(CXZX2017582);福建农林大学科技创新专项基金项目 (CXZX2017353)。

作者简介:杨国永,男,福建漳州人,副教授, 主要研究方向为土地、住房与城乡发展。E-mail: 52128781@qq.com

通讯作者:许文兴,男,福建莆田人,教授,主要研究方向为农业经济管理。E-mail: fjxwx@sina.com 
多。Arif ${ }^{60}$ 认为移民回乡建房除了建设房产, 并没有 使移民和他们的家庭受益, 却加大了贫富差距。为 实现回家乡建设住房的目标, 许多移民在移居地居 住在拥挤社区或郊区废弃的房屋 ${ }^{[7]}$ 。此外, Osili ${ }^{[8]}$ 的 研究发现, 由于缺乏完善的房屋租赁和转售市场, 移民并没有获得直接的好处来抵消与家乡住房投 资有关的成本, 使得标准投资模式难以解释移民家 乡住房投资行为。国内学术界也没有单独对农民工 回乡建房影响的研究成果, 仅有少数学者在研究农 民工城市化问题时提及建房的影响。例如, 董昕等 ${ }^{[9]}$ 研究发现, 老家自建房显著影响农民工家庭在流人 地的住房消费 (居住支出), 且作用为负。刘林平等 ${ }^{[10]}$ 认为, 农村的新建住房还会显著影响农民工进城落 户的意愿, 导致农民工农村住房过剩与城市住房不 足并存的矛盾 ${ }^{[11,12]}$ 。厉以宁以 “两只老鼠” 的故事 ${ }^{11}$ 对此进行形象比喻 ${ }^{[13]}$ 。此外, 胡建坤等 ${ }^{[14]}$ 也指出农 民工回乡建房包含着很多的无奈, 造成了资源配置 上的不经济。综合来看, 上述学者均是在相关研究 中略带提及农村住房对农民工家庭的影响, 但没有 作进一步的深人分析, 对回乡建房之于农民工家庭 的居住福利、经济效应和社会符号价值等方面的影 响研究尚未触及。

虽然福利问题一直受到国内外学者的重视, 是 社会经济发展领域的重要研究课题 ${ }^{[15]}$, 但学术界还 没有将其应用于农民工回乡建房, 以及根据回乡建 房特征对一般福利理论模型进行修正的先例。相 对于近一半农民工回乡建房的社会现象而言, 学术 界的相关研究尤显滞后。由此, 本文把以往为数不 多的农民工回乡建房影响的考察, 推进到对农民工 回乡建房家庭福利效应的研究, 试图拓展农民工议 题的研究视野, 丰富该领域学术理论积累, 希望有 助于深化对此现象的理解, 为政府制定政策破解农 民工城乡住房困境提供理论认知与现实指引。

\section{2 理论基础与分析框架}

\section{1 理论基础}

20 世纪 $80-90$ 年代, 在批判传统福利经济学理
论的基础上,阿玛蒂亚・森创设福利的可行能力理 论。其核心是用“个人能够实现有价值活动的可行 能力”来评价生活质量 ${ }^{[16]}$, 并主张影响人们福利水平 的不是所拥有的物品, 而是物品可以为人们带来什 么, 以及人们可以利用物品做成什么 ${ }^{[17]}$ 。该理论把 福利定义为“个人值得去做或达到的事情和状态, 即功能性活动, 以及人们想要做到的事情和达到的 状态的自由, 即可行能力” ${ }^{[18]}$ 。其中, 功能性活动强 调实际做到的,包括五项功能性活动, 即透明性保 证、社会机会、经济条件、政治自由和防护性保障 等; 可行能力则关注是否有实质的自由, 反映个人 可以获得福利的机会和选择的自由。阿玛蒂亚・森 指出, 可行能力难以被直接观测到, 但对功能性活 动的测量可以实现对福利状况的评价。此外,功能 性活动和可行能力与个人特征和客观环境联系紧 密。个体和环境因素的差异会导致相同的商品和 服务对不同的人产生不同的福利,或者说会转换成 不同的功能性活动。这些因素被称为福利的转换 因素,主要包括五大类:人际关系的差别、个人的异 质性、环境的多样性、家庭内部的分配和社会氛围 的差异 ${ }^{[18]}$ 。相比传统福利理论, 可行能力理论较好 地规避了资源或收人指标的单一局限性 ${ }^{[19]}$, 以更全 面完整的理论框架获得学术界认同并被推广应用 ${ }^{[17]}$ 。 例如联合国发展计划署(UNDP)运用该理论方法开 发“人类发展指数” ${ }^{[19]}$, 在年度发展报告中广泛使用, 并在全球形成重要影响。近年,国内学者参照可行 能力理论的分析框架对城市和农村家庭福利开展 实证研究。其中,高进云等 ${ }^{[17]}$ 第一次把该分析框架 引到国内, 对失地农民福利状况开展实证研究。其 后,贾燕等 ${ }^{[20-23]}$ 也将该理论框架应用到农户集中居 住前后的福利变化研究中。

\section{2 分析框架}

\subsection{1 农民工回乡建房福利的功能性活动指标}

可行能力理论所确定的功能性活动指标和转 换因素总体上比较抽象。学术界在应用该理论进行 具体问题分析时,更多的是根据各自研究主题和调查

(1) 对于农民工城乡住房矛盾困境,著名经济学家厉以宁曾以“两只老鼠”的故事进行形象比喻:“有的农民带着老婆孩子外出打工,房子一 把锁锁上,结果变成了老鼠窝; 进城的时候两手空空,没有钱,一家子只能住地下室,成了“鼠族””。这个比喻反映了当前农民工所面临的住房 困境与无奈选择,也折射了中国城乡住房体系的内在矛盾。 
此,本文选取了负债金额、农村月均居住成本、经济

群体的特征进行选取，但并未达成一致意见 ${ }^{[24-26] 。 ~}$ 而这也是可行能力理论所允许的 ${ }^{[18]}$ 。本文研究目标 之一是评价农民工回乡建房的家庭福利效应, 在某 种程度上与农户集中居住福利相近。因此, 前人有 关居住福利的功能性活动指标能为本文提供直接 参考和借鉴。归纳起来,学术界构建的农户集中居 住福利的功能性活动指标, 包括社会机会、防护性 保障、经济条件、政治自由、居住环境、社区生活、心 理情感和住房条件等; 转换因素则包括个人特征因 素 (性别、年龄、受教育程度)、家庭特征因素 (劳动 力平均年龄、劳动力非农就业比重、被抚养人口占 家庭总人口的比重）、区域特征因素、集中居住时 间等 ${ }^{[20-23]}$ 。

然而, 由于多数农民工回乡建房后选择继续外 出, 实际居住福利获得较小。因此, 上述农户集中 居住福利指标对本研究并不是完全适用的。此外, 农民工回乡建房不仅仅是个人选择, 而是家庭集体 决策的结果。而且, 建房是农民工家庭的大事, 关 涉家庭全体成员的福利。因此, 在设定福利指标 时, 应该从家庭整体福利进行考虑。本文以阿玛蒂 亚 - 森的可行能力理论为基础, 参照其所提出的五 项指标,借鉴居住福利指标, 结合农民工回乡建房 的实际影响, 并以函询形式咨询相关专家, 最终构 建了回乡建房农民工家庭福利的功能性活动指标 体系, 包括家庭经济、家庭发展机会与社会资本、家 庭保障、家人心理情感、家庭住房与居住满足。

(1) 家庭经济。虽然阿玛蒂亚・森强调以经济 状况作为衡量福利的唯一指标过于局限, 收人更无 法代表福利的全部内涵, 但他并没有否认经济状况 的重要性。事实上, 他还强调收人不仅是福利的物 质基础, 更是获取福利的重要途径 ${ }^{[27]}$ 。而且与收人 紧密相关的支出还会对家庭经济状况产生重要影 响。国内学术界所构建的农户集中居住福利的经 济状况指标, 主要包括收人、支出、补偿评价、经济 满意度和贷款等 ${ }^{[20-23]}$ 。由于农民工回乡建房鲜少出 于投资目的,用于出租实现其资产价值的非常少 ${ }^{[2]}$,增 值获利的可能性也很小。回乡建房对农民工家庭 经济的影响主要体现在因建房所产生的负债压力、 日常居住支出, 以及家庭经济可自由支配情况。由
自由度主观感受等指标反映家庭经济。

(2)家庭发展机会与社会资本。阿玛蒂亚・森 所确定的社会机会指标指的是 “在社会教育、医疗 保健及其他方面所实行的安排,它们影响个人赖以 享受更好的生活的实质自由”, 是人重要的非物质 福利 ${ }^{[18]}$ 。国内学术界所构建的农户集中居住福利的 社会机会指标,主要包括就业机会、教育资源、发展 空间、获取信息便捷度、人际关系、朋友交往密切程 度等 ${ }^{[20-23]}$ 。在 “熟人”或“半熟人”社会的农村,村社 内部的人际交往形式除了公共空间的集体活动之 外,还有很重要的一种形式是到彼此住房内“串门” 交往。因此,住房也就成为影响交往程度和频率的 重要因素。此外,住房不只是满足居住属性的物质 实体, 还是一种符号性消费活动的载体, 更是社会 地位的重要象征 ${ }^{[28]}$ 。在农村,住房规模和档次从某 种意义上反映了家庭实力和主要劳动力的能力。 住房面积越大、质量越好, 在一定程度上越能为家 庭赢得同村人的认可，也使得家人更有信心、更容 易拓展社会资源, 比如更方便向他人拆借筹款、发 展事业。因为新建住房往往被认为是一种最为稳 定的抵押和有形的信用保证。新建住房还使得男 方获得女方更高的认可度, 从而扩大婚姻匹配范 围, 促进较高质量的婚姻缔结。因此, 本文选取了 亲戚朋友、邻居、村干部、工友同事的态度,农村老 家朋友交往度,娶亲婚嫁难易程度等指标反映家庭 发展机会与社会资本,对应可行能力理论中的社会 机会和透明性保障这两个功能性活动。

(3) 家庭保障。阿玛蒂亚・森在描述功能性活 动时, 特别强调社会保障的防护性作用 ${ }^{[23]}$ 。但本文 调查发现,农民工享有的社会保险多为自愿办理, 回乡建房前后其种类和覆盖面并没有多大变化,故 此处没有列人社会保险指标。本部分侧重从物化 角度评价家庭保障状况。对中国农民而言, 土地在 赋予农民基本生活保障的同时也兼具失业、养老等 社会保障功能 ${ }^{[29]}$ 。而农民工回乡建房前后, 所占用 的宅基地面积可能发生变化,而且普遍增加。此 外,住房是人类生存和发展的基础资料。农民更是 将农村住房视为家庭最基本的保障。尤其对外出 
农民工而言, 在农村有了房才感觉有了“根”。在中 国, 只有农村集体成员才能获得宅基地使用权。而 且, 随着《物权法》颁布实施, 农村土地确权登记工 作的推进,近年农民对住房产权意识逐渐被唤醒, 认识到土地使用权和住房所有权保护对家庭财产 保障的重要性。此外, 近些年农村建房质量和建筑 安全也是农民建房时考虑的重点之一。因此, 本文 选取了宅基地面积、住房产权保障、房屋建筑安全 性对应可行能力理论的防护性保障这一功能性 活动。

(4)家人心理情感。良好的居住条件与健康的 心理和生理密切相关 ${ }^{[30]}$ 。农村住房还是家庭实力的 反映, 具有符号象征意义, 并成为外界对自家评价 的重要依据之一, 也是农民在村庄里有没有“面 子”, 能不能保住 “面子”, 挣得 “面子”的关键。而在 传统农村的“熟人社会”里, “面子”问题直接影响农 民心理感受以及家庭气氛。同时, 在城市习得的消 费主义生活方式, 也会成为农民工检视家庭生活质 量的参照, 或获得一定的心理满足, 或产生一定的 心理落差。因此,本文选取了家庭气氛、社会地位 的自我认同和对未来生活的预期,评价回乡建房前 后农民工及其家人心理情感的变化。

(5)家庭住房与居住满足。良好居住是福利的 重要内容。随着居住条件改善, 人们越来越注重住 房的舒适程度。一般来说, 农民工回乡建房后, 家庭 居住条件都会有所改善,表现在人均住房面积、住 房结构和生活设施等方面的进步。其中, 人均住房 面积反映房屋的舒适程度; 住房结构和生活设施反 映居住房屋品质的好坏 ${ }^{[20]}$ 。此外, 住房的最基本功 能是居住消费, 能为人们遮风挡雨、驱寒保暖。人 们只有实际居住使用了, 才能真正享受住房所带来 的消费福利。然而,农民工每年在农村居住时间有 限, 其享受到的新建住房福利可以说是很少的, 而能 够真正享受新建住房福利的更多是留守农村的家 人。因此, 本文选取农村人均住房面积、住房结构、 住房设施、农村住房家庭人口实际使用比例等衡量 农民工家庭住房与居住满足这一功能性活动。

2.2.2 农民工回乡建房福利的转换因素 诚如上文所述, 学术界更多的是根据各自研究
主题和调查群体的特征选取相关指标, 以对应阿玛 蒂亚・森所主张的转换因素。高进云等 ${ }^{[17]}$ 指出, 不同 地区的人们可获得的功能性活动与当地社会经济 条件紧密相关。对于农民工回乡建房而言, 由于不 同流出地的经济社会发展情况差别较大。相应地, 农民工回乡建房前后福利变化也会有所不同。因 此,本文以所在设区市反映可行能力理论所提出的 环境的多样性。而乡镇政府附近是所在区域的中 心, 公共设施相对完备, 人口也较密集, 商业氛围也 更浓厚。因此,所在村庄与乡镇政府距离不同, 村 庄内部的社会氛围、人际关系也是有所差异的, 居 住便利性也不同。本文以村庄与乡镇政府距离对 应可行能力理论所提出的人际关系差别、社会氛围 差异等。而不同代际的农民工对农村住房的观念 认识不同,特别对建房在农村的符号象征的认同也 有差异, 由此产生了不同心理感受。因此本文以代 际对应可行能力理论的个人的异质性。此外, 高进 云等 ${ }^{[17]}$, 贾燕等 ${ }^{[2]}$ 研究发现家庭特征 (被抚养人口占 家庭总人口的比重、教育程度)影响农户福利。而 且本文以农民工家庭为分析单位, 并将家庭进行人 格化, 因此家庭特征在一定程度上也能代表阿玛蒂 亚・森所强调的个人的异质性。依照新劳动迁移经 济理论,外出工作是移民家庭基于全家整体福利最 大化的隐性协议安排 ${ }^{[8]}$ 。换言之, 外出农民工与原 生家庭之间存在隐性借贷合约关系 ${ }^{[31]}$, 即原生家庭 为外出者承担部分迁移成本或此前的养育费用,外 出者则会以汇款偿还或补偿原生家庭的投资 ${ }^{[32,33]}$ 。 因此, 本文以建房前外出人口占比来反映家庭内部 的分配。综上所述,本文确定了农民工家庭所在的 设区市 $\left(T_{1}\right)$ 、所在村庄与乡镇政府距离 $\left(T_{2}\right)$ 、代际 $\left(T_{3}\right)$ 、建房前外出人口占比 $\left(T_{4}\right)$ 作为农民工回乡建 房家庭福利的转换因素。

\section{3 研究方法与数据来源}

\section{1 研究方法}

\subsection{1 福利的模糊数学综合评价法}

阿玛蒂亚・森认为福利不是一个非此即彼的绝 对概念, 而是一个模糊的相对概念 ${ }^{[18]}$, 难以用经典数 学和统计数学方法进行量化描述和分析。回乡建 房农民工家庭福利涉及家庭经济、居住条件、家人 


$$
\mu_{\omega}\left(\chi_{i j} ; a, b\right)= \begin{cases}0, & \chi_{i j} \leqslant a \\ \chi_{i j}-a & a<\chi_{i j}<b \\ b-a & \chi_{i j} \geqslant b\end{cases}
$$

用模糊数学方法 ${ }^{[34]}$ 。

(1) 模糊函数设定。将回乡建房农民工家庭福 利状况设为模糊集 $\mathbf{X}$, 回乡建房后可能变化的福利 内容设为 $\mathbf{X}$ 的子集 $\mathbf{W}$, 那么第 $n$ 个农民工家庭的福 利函数可以用 $\mathbf{W}^{(n)}=\left|\boldsymbol{\chi}, \mu_{\omega}(\boldsymbol{\chi})\right|$ 表示, 其中 $\boldsymbol{\chi} \in \mathbf{X}, \mu_{\omega}(\boldsymbol{\chi})$ 是 $\boldsymbol{\chi}$ 对 $\mathbf{W}$ 的隶属度, $\mu_{\omega}(\chi) \in[0,1]$ 。设定隶属度越大福利 状况越好: 即隶属度为 0 时, 福利状况绝对差; 为 1 时, 福利处于绝对好的状况; 等于 0.5 时最模糊, 处 于中等水平 ${ }^{[17]}$ 。

(2) 隶属函数设定。运用模糊数学的关键是选 择适合的隶属函数。而隶属函数又取决于功能性 活动指标。一般指标可以分为虚拟二分变量、虚拟 定性变量和连续变量等三种类型。设 $\chi_{i}$ 是农民工家 庭福利的第 $i$ 个功能子集, 并由初级指标 $\boldsymbol{\chi}_{i j}$ 所决定, 即回乡建房农民工家庭福利的初级指标为 $\chi=\left[\chi_{11}, \cdots, \chi_{i j}, \cdots\right]$ 。对于连续变量, Cerioli 等 ${ }^{[35]}$ 将其 $^{-}$ 隶属度函数设定为:

$$
\mu_{\omega}\left(\chi_{i j} ; a, b\right)= \begin{cases}0, & 0 \leqslant \chi_{i j} \leqslant a \\ \chi_{i j}-a & a<\chi_{i j}<b \\ b-a & \chi_{i j} \geqslant b\end{cases}
$$

式中: $a 、 b$ 为参数, 且 $b>a$ 。 $\chi_{i j}$ 表示指标与福利状况 之间的关系为正向相关, 即 $\chi_{i j}$ 越大, 则福利状况越 好, $\mu_{\omega}\left(\chi_{i j} ; a, b\right)$ 值越大, 则说明回乡建房农民工家庭 的福利状况越好 ${ }^{[35]}$ 。

$$
\mu_{\omega}\left(\chi_{i j} ; a, b\right)= \begin{cases}1, & 0 \leqslant \chi_{i j} \leqslant a \\ b-\chi_{i j} & a<\chi_{i j}<b \\ b-a & \chi_{i j} \geqslant b\end{cases}
$$

式中: $a$ 为指标 $\chi_{i j}$ 的下限, 如果 $\chi_{i j} \leqslant a$, 那么福利状况就 是最差的; $b$ 为指标 $\chi_{i j}$ 的上限, 如果 $\chi_{i j} \geqslant a$, 那么福利状 况就是最好的。

现实世界里,有些问题难以量化表示, 只能定性 描述, 即为虚拟定性变量。一般假设研究问题有 $m$ 种 状态, 依次等距离赋值 $x_{i j}=\left\{x_{i j}^{(1)}, \cdots, x_{i j}^{(m)}\right\}$, 并假设 $x_{i j}^{(1)}<\cdots<x_{i j}^{(k)}<x_{i j}^{(m)}$, 且 $x_{i j}^{(k)}=k(k=1, \cdots, m)$ 。

Cerioli 等 ${ }^{[35]}$ 设定这类变量的隶属度函数如下式 所示:

式中: $a$ 和 $b$ 分别是 $\chi_{i j}$ 的最大值和最小值 ${ }^{[35]}$ 。

(3)权重计算。初级指标隶属度确定后,需要按 照一定的权重进行加总。而最常用的是 Cheli 等 ${ }^{[36]}$ 所提出的权重计算公式:

$$
\omega_{i j}=\ln \left[\frac{1}{\overline{\mu\left(\chi_{i j}\right)}}\right]
$$

式中: $\overline{\mu\left(\chi_{i j}\right)}=\frac{1}{n} \sum_{p=1}^{n} \mu\left(\chi_{i j}\right)^{(p)}$, 表示 $n$ 个回乡建房农 民工家庭第 $i$ 个功能子集中的第 $j$ 项指标均值。然后, 再根据初级指标隶属度和权重计算各功能子集的 隶属度,本文采用 Cerioli等 ${ }^{[35]}$ 所提出的加总公式:

$$
f\left(x_{i}\right)=\sum_{i=1}^{k} \overline{\mu\left(\chi_{i j}\right)} \times \omega_{i j} / \sum_{j=1}^{k} \omega_{i j}
$$

式中: $k$ 表示在第 $i$ 个功能子集中包含了 $k$ 个初级 指标。

\subsection{2 反映福利差异的“洛伦兹”曲线}

目前评价收人分配差异最常用的指标是基尼 系数 (Gini Coefficient), 或称洛伦兹系数 (Lorenz Coefficient), 其值介于 $0 \sim 1$ 之间。该系数越大,说明 收人分配差异越大。但正如阿玛蒂亚・森所指出, 对于福利衡量来说, 收人指标还是过于单一, 无法 充分反映包括自由、健康、社会关系和心理感受等 更多的福利潜在内涵 ${ }^{[18]}$ 。除了极小部分为出租或经 营所需, 大部分农民工回乡建房的目的并不是为了 提高收人,而是为了改进家庭的整体福利。本文借 鉴洛伦兹系数的计算方法,测算回乡建房前后农民 工家庭福利变化差距,并定义回乡建房的不同农民 工家庭之间福利差异为 “福利差异系数”。与基尼 系数值的涵义相类似, 福利差异系数值介于 $0 \sim 1$ 之 间。该系数越大,说明农民工家庭之间的福利差异 越大, 反之则越小。参照洛伦兹系数的计算公式, 本文计算回乡建房农民工家庭福利差异系数, 具体 公式如下:

$$
H=1-\frac{1}{N-1} \sum_{i=1}^{N-1}\left(Y_{i}+Y_{i+1}\right)
$$

式中: $H$ 代表福利差异系数, $Y_{i}$ 代表第 1 至第 $i$ 个农民 
工家庭福利指数占加总福利指数的累加比重, $N$ 为 农民工家庭总数。

\section{2 数据来源}

\subsection{1 抽样方法}

新迁移经济理论认为移民迁移行为不只是个 体决策的结果, 而是家庭分工决定的结果; 移民住 房投资决策考虑的是家庭整体利益最大化, 而不仅 仅是个人收益最大化 ${ }^{[37]}$ 。虽然本文的研究对象是外 出农民工回乡建房, 即农民工外出工作期间, 把收 人带回农村老家, 投人到住房建设 ${ }^{[14]}$ 。但在中国农 村, 建房是农民家庭集体决策的行动。本文以农民 工家庭作为分析单位, 并将其界定为本文观测期末 家里有一位及以上外出农民工的家庭。

外出农民工回乡建房行为发生在农民工流出 地的时空场域中, 并受到流出地家庭、村社和区域 等多方面因素的影响。因此,本文在福建省农民工 流出地进行抽样调查, 采取“设区市一县(市)一乡 (镇)一行政村一农民工家庭”多阶段分层抽样方法 选取调查样本家庭。最终在福建省 3 个设区市、6个 县 (市)、12 个乡(镇)、24 个村选取 840 个农民工家 庭 (每个村随机选取 35 个样本家庭), 于 2017 年春 节期间开展人户问卷调查, 共回收 815 份, 回收率 $97.02 \%$; 剔除关键变量缺失的样本, 最终获得有效 问卷 695 份, 有效率 $85.28 \%$ 。根据自第一位成员第 一次外出工作以来家庭是否建房, 将样本分为“曾 经回乡建房农民工家庭”(326个)和“没有回乡建房 农民工家庭”(369个 $)^{[5]}$ 。

\subsection{2 样本特征}

本文研究目的是分析回乡建房前后农民工家 庭福利效应, 因此只利用曾经回乡建房的 326 个调 查样本数据进行分析。为更清楚地呈现这 326 个样 本的特征, 本部分与 695 个所有调查样本的关键特 征变量进行比较,具体如表 1 。

\section{3 指标定义与描述性统计}

本文以农民工回乡建房时间 (从开始动工建房 到建设完工)为间隔,之前一年为“回乡建房前”, 建 设完工后的一年为“回乡建房后”。表 2 中变量类型 $Q$ 代表“虚拟定性指标”, $C$ 代表 “连续型指标”。此 外, 由于样本家庭的建房时间非常分散, 受物价变
表 1 农民工回乡建房调查样本特征

Table 1 Characteristics of the survey samples

\begin{tabular}{lccc}
\hline & $\begin{array}{c}\text { 所有调查 } \\
\text { 样本 }(n=695)\end{array}$ & $\begin{array}{c}\text { 曾经回乡建房 } \\
\text { 样本 }(n=326)\end{array}$ & 差值 \\
\hline 家庭人口/人 & 4.36 & 4.67 & -0.31 \\
子女中男性人口/人 & 1.27 & 1.39 & -0.12 \\
家庭代际数/代 & 2.47 & 2.55 & -0.08 \\
常住农村老家人数/人 & 2.22 & 2.51 & -0.29 \\
外出工作人数/人 & 1.75 & 1.81 & -0.06 \\
\hline
\end{tabular}

动影响, 所涉资金不具有可比性。为此,本文以 1990 年为基年对所涉资金数据进行换算。从表 2 可 以看出, 除了家庭经济外,其他指标在农民工回乡 建房后都有所改善, 但总体福利发生如何变化,还 需要进一步的实证分析。

\section{4 结果与分析}

\section{1 农民工家庭各功能性活动的福利变化}

\subsection{1 功能性活动指标评价结果分析}

本部分采用模糊综合评价方法,计算各功能性 活动及其子指标的隶属度和权重。一般而言, 隶属 度介于 $0.400 \sim 0.600$ 之间的表示福利居于中间水平， 低于 0.400 表示处于低水平,而高于 0.600 的则说明 福利水平比较高。从表 3 的统计结果可以看出, 回 乡建房后农民工家庭的总福利水平有所提升, 从回 乡建房前隶属度 0.363 的较差水平提升到回乡建房 后隶属度 0.488 的中间水平,但仍然低于 0.500 的中 等水平。从各功能性活动指标变化程度看, 除了家 庭经济外,其他方面的功能水平均有所上升。其中 家庭住房与居住环境状况改善最明显,其次是家庭 发展机会与社会资本,具体如下。

(1) 家庭经济。农村月均居住成本隶属度从回 乡建房前 0.710 降为 0.649 , 这可能是因为建房后家 庭住房面积普遍增大, 并配备了更多电器, 日常打 扫保洁等导致了水电费用支出增多,增加了居住成 本。而部分家庭因建房向亲戚朋友借了钱,负债金 额的隶属度也由 1.000 降为 0.901 。此外, 由于建房 几乎动用了全家多年积蓄, 因此可能造成农民工家 庭经济自由度降低, 总体上导致家庭经济隶属度由 0.710 降为 0.649 , 说明农民工家庭经济状况在回乡 建房之后下降了。

(2)家庭发展机会与社会资本。从建房前后隶 
表 2 农民工回乡建房家庭福利指标定义与描述性统计

Table 2 Definition and descriptive statistics of welfare indicators

\begin{tabular}{|c|c|c|c|c|c|c|c|}
\hline \multirow{2}{*}{$\begin{array}{l}\text { 功能性活动 } \\
\text { 与指标变量 }\end{array}$} & \multirow{2}{*}{ 定义与赋值 } & \multirow{2}{*}{$\begin{array}{l}\text { 变量 } \\
\text { 类型 }\end{array}$} & \multicolumn{2}{|c|}{ 回乡建房前 } & \multicolumn{2}{|c|}{ 回乡建房后 } & \multirow{2}{*}{$\begin{array}{l}\text { 均值 } \\
\text { 差异 }\end{array}$} \\
\hline & & & 均值 & 标准差 & 均值 & 标准差 & \\
\hline \multicolumn{8}{|l|}{ 家庭经济 } \\
\hline 农村月均居住成本 & $\begin{array}{l}\text { 取实际支出/元 ( 以 } 1990 \text { 年为 } \\
\text { 基年) }\end{array}$ & $C$ & 96.00 & 63.00 & 115.00 & 73.00 & 19.00 \\
\hline 负债金额 & $\begin{array}{l}\text { 取实际负债金额/元 ( 以 } 1990 \\
\text { 年为基年) }\end{array}$ & $C$ & 0.00 & 0.00 & 22877.00 & 31944.00 & 22877.00 \\
\hline 家庭经济自由度 & $\begin{array}{l}\text { 非常不满意 }=1 \text {; 比较不满意 }= \\
2 ; \text { 一般 }=3 \text {; 比较满意 }=4 \text {; 非常 } \\
\text { 满意 }=5\end{array}$ & $Q$ & 3.63 & 0.87 & 3.20 & 0.83 & -0.43 \\
\hline \multicolumn{8}{|c|}{ 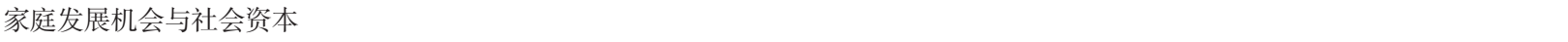 } \\
\hline $\begin{array}{l}\text { 亲戚朋友、邻居、村干 } \\
\text { 部、工友同事的态度 }\end{array}$ & $\begin{array}{l}\text { 非常尊重 }=5 \text {; 比较尊重 }=4 \text {; 一 } \\
\text { 般 }=3 \text {; 比较不尊重 }=2 \text {; 非常不 } \\
\text { 尊重 }=1\end{array}$ & $Q$ & 3.21 & 0.55 & 3.58 & 0.64 & 0.37 \\
\hline 娶亲婚嫁难易程度 & $\begin{array}{l}\text { 非常容易 }=5 \text {; 比较容易 }=4 \text {; 一 } \\
\text { 般 }=3 \text {; 比较难 }=2 ; \text {; 非常难 }=1\end{array}$ & $Q$ & 2.96 & 0.71 & 3.70 & 0.79 & 0.74 \\
\hline 农村老家朋友交往度 & $\begin{array}{l}\text { 非常高 }=5 ; \text { 比较高 }=4 ; \text { 一般 }= \\
3 ; \text { 比较低 }=2 ; \text { 非常低 }=1\end{array}$ & $Q$ & 3.12 & 0.55 & 3.46 & 0.66 & 0.34 \\
\hline \multicolumn{8}{|l|}{ 家庭保障 } \\
\hline 宅基地面积 & 取实际面积/m² & $C$ & 132 & 82.00 & 181.00 & 133.00 & 49.00 \\
\hline 房屋建筑安全性 & $\begin{array}{l}\text { 非常安全 }=5 ; \text { 比较安全 }=4 ; \text { 一 } \\
\text { 般 }=3 \text {; 比较不安全 }=2 \text {; 非常不 } \\
\text { 安全 }=1\end{array}$ & $Q$ & 2.94 & 0.96 & 4.25 & 0.66 & 1.31 \\
\hline 住房产权保障 & $\begin{array}{l}\text { 房屋所有权证 }=4 \text {; 国有土地 } \\
\text { 使用权证 }=3 \text {; 集体土地使用 } \\
\text { 权证 }=2 \text {; 无产权证明 }=1\end{array}$ & $Q$ & 2.27 & 0.86 & 2.28 & 0.84 & 0.01 \\
\hline \multicolumn{8}{|l|}{ 家人心理情感 } \\
\hline 家庭气氛 & $\begin{array}{l}\text { 非常好 }=5 \text {; 比较好 }=4 \text {; 一般 }= \\
3 \text {; 比较差 }=2 \text {; 非常差 }=1\end{array}$ & $Q$ & 3.87 & 0.80 & 4.28 & 0.69 & 0.41 \\
\hline 社会地位的自我认同 & $\begin{array}{l}\text { 上层 }=5 ; \text { 中上层 }=4 ; \text { 中层 }=3 ; \\
\text { 中下层 }=2 ; \text { 下层 }=1\end{array}$ & $Q$ & 2.85 & 0.57 & 3.27 & 0.60 & 0.42 \\
\hline 对未来生活的预期 & $\begin{array}{l}\text { 非常乐观 }=5 \text {; 比较乐观 }=4 ; \text { 一 } \\
\text { 般 }=3 \text {; 比较不乐观 }=2 \text {; 非常不 } \\
\text { 乐观 }=1\end{array}$ & $Q$ & 3.37 & 0.74 & 3.83 & 0.76 & 0.46 \\
\hline \multicolumn{8}{|l|}{ 家庭住房与居住满足 } \\
\hline 农村人均住房面积 & 取实际面积/m² & $C$ & 31.00 & 22.00 & 87.00 & 45.00 & 56.00 \\
\hline 农村住房结构 & $\begin{array}{l}\text { 框架结构 }=5 \text {; 砖混结构 }=4 \text {; 砖 } \\
\text { 木结构 }=3 \text {; 土坏结构 }=2 \text {; 其他 } \\
\text { 结构 }=1\end{array}$ & $Q$ & 2.54 & 0.81 & 4.17 & 0.54 & 1.63 \\
\hline 农村住房设施 & $\begin{array}{l}\text { 非常完善 }=5 \text {; 比较完善 }=4 ; \text { 一 } \\
\text { 般 }=3 \text {; 比较不完善 }=2 \text {; 非常不 } \\
\text { 完善 }=1\end{array}$ & $Q$ & 2.46 & 0.81 & 3.90 & 0.69 & 1.44 \\
\hline $\begin{array}{l}\text { 农村住房家庭人口 } \\
\text { 实际使用比例 }\end{array}$ & $\begin{array}{l}\text { 留守农村人口占家庭总人口 } \\
\text { 比例 } / \%\end{array}$ & $C$ & 52.06 & 27.00 & 58.86 & 20.97 & 6.80 \\
\hline
\end{tabular}

属度比较看, 回乡建房使农民工家庭感受到的外界 态度、娶亲婚嫁难易程度、农村老家朋友交往度等 方面都得到改善。其中,娶亲婚嫁难易程度改善程 度最大, 而且达到较高水平 (隶属度超过 0.600 ), 说 明建房在农村婚嫁缔结中的重要地位。

(3)家庭保障。从表3 可以看出, 回乡建房前后
农民工家庭的房屋建筑安全得到大幅改善。这可 能是由于原有住房多为砖木或砖混结构,甚至还有 部分为土坏结构,而新建住房则以砖混结构为主, 部分为框架结构。此外,回乡建房后一年宅基地占 用面积较建房前一年增大。这与农民工家庭为建 房而另辟新地,且建新不拆旧有关。因部分原有住 
表3 农民工回乡建房家庭福利的功能性活动隶属度和权重

Table 3 Membership and weight of indicators

\begin{tabular}{|c|c|c|c|c|}
\hline \multirow{2}{*}{ 功能性活动与指标变量 } & \multicolumn{2}{|c|}{ 隶属度 } & \multicolumn{2}{|c|}{ 权重 } \\
\hline & 建房前 & 建房后 & 建房前 & 建房后 \\
\hline 家庭经济 & 0.710 & 0.649 & 0.048 & 0.112 \\
\hline 农村月均居住成本 & 0.829 & 0.791 & 0.015 & 0.028 \\
\hline 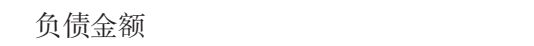 & 1.000 & 0.901 & 0.033 & 0.072 \\
\hline 家庭经济自由度 & 0.656 & 0.550 & 0.000 & 0.012 \\
\hline 家庭发展机会与社会资本 & 0.522 & 0.643 & 0.153 & 0.158 \\
\hline 亲戚朋友、邻居、村干部、工友同事的态度 & 0.552 & 0.644 & 0.047 & 0.053 \\
\hline 娶亲婚嫁难易程度 & 0.490 & 0.675 & 0.056 & 0.047 \\
\hline 农村老家朋友交往度 & 0.531 & 0.615 & 0.050 & 0.058 \\
\hline 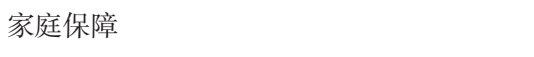 & 0.259 & 0.294 & 0.294 & 0.339 \\
\hline 宅基地面积 & 0.117 & 0.171 & 0.169 & 0.212 \\
\hline 房屋建筑安全性 & 0.485 & 0.813 & 0.057 & 0.025 \\
\hline 住房产权保障 & 0.423 & 0.423 & 0.068 & 0.103 \\
\hline 家人心理情感 & 0.555 & 0.657 & 0.129 & 0.133 \\
\hline 家庭气氛 & 0.717 & 0.820 & 0.026 & 0.024 \\
\hline 社会地位的自我认同 & 0.462 & 0.568 & 0.061 & 0.068 \\
\hline 对未来生活的预期 & 0.591 & 0.707 & 0.041 & 0.041 \\
\hline 家庭住房与居住满足 & 0.270 & 0.490 & 0.376 & 0.258 \\
\hline 农村人均住房面积 & 0.104 & 0.308 & 0.179 & 0.141 \\
\hline 农村住房结构 & 0.385 & 0.794 & 0.075 & 0.028 \\
\hline 农村住房设施 & 0.366 & 0.725 & 0.079 & 0.039 \\
\hline 农村住房家庭人口实际使用比例 & 0.578 & 0.654 & 0.043 & 0.051 \\
\hline 总模糊指数 & 0.363 & 0.488 & 1.000 & 1.000 \\
\hline
\end{tabular}

房与邻居同墙共壁, 而邻居不一定能同步翻建, 且 原有住房多处村庄内部, 交通不便, 农民工家庭不 愿翻建,也难以翻建。因此,近年农村部分新房是 建在耕地,或集体规划的新村小区,或在公路沿线 新辟的宅基地上。然而, 在住房产权保障上, 建房 前后并没有改变。这可能是因为在过往多年中, 福 建各地基本没批准农村家庭自建房,相应的土地使 用权证、房屋所有权证也就无法办理; 而且因无法 交易或抵押流转, 即便办了产权证, 短期内也没什 么实际用途。

(4)家人心理情感。住房是农村家庭最重要的 资产, 也是农民倾其一生, 并举全家之力努力要完 成的目标, 对每个家庭成员来说都是大事。因此, 回乡建房能够明显改善家庭气氛、自我认同感, 以 及对未来生活的预期。从表 3 可以看出, 回乡建房 后, 家人心理情感隶属度从 0.555 上升到 0.657 ; 而且 家庭气氛、对未来生活的预期也都处在较高水平
（隶属度均超过 $0.600 ） 。$

(5)家庭住房与居住满足。回乡建房对农民工 家庭住房与居住环境改善比较明显, 隶属度由建房 前的 0.270 提高到建房后的 0.490 。其中, 农村住房 结构变化最大, 隶属度提高了一倍多, 达到 0.794 ,其 次是住房设施获得了明显改善。此外,建房后,农 村住房实际使用比例也更高了。这与部分农民工 建房是为了返乡居住不无关系, 同时农村住房条件 改善了,农民工或许也更喜欢回家小住,或住的时 间比以前更长了。

\subsection{2 各功能隶属度农民工家庭比重分布}

表 4 显示了回乡建房前后农民工家庭各功能隶 属度分布的变化情况。从整体上看, 建房前大部分 农民工家庭隶属度分布在 $(0.301,0.400]$, 而建房后 则大部分分布在 $(0.401,0.500]$, 还有 $31.29 \%$ 的农民 工家庭分布在 $(0.501,0.600]$ 。从以上数据可以看 出, 回乡建房使得大部分农民工家庭福利整体上获 
表 4 各功能隶属度回乡建房农民工家庭比重分布

Table 4 Proportion of family members of migrant workers returning home to build houses by membership value range

\begin{tabular}{|c|c|c|c|c|c|c|c|c|c|c|c|c|}
\hline \multirow{2}{*}{$\begin{array}{c}\text { 隶属度 } \\
\text { 区间分布 }\end{array}$} & \multicolumn{2}{|c|}{$X_{1}$} & \multicolumn{2}{|c|}{$X_{2}$} & \multicolumn{2}{|c|}{$X_{3}$} & \multicolumn{2}{|c|}{$X_{4}$} & \multicolumn{2}{|c|}{$X_{5}$} & \multicolumn{2}{|c|}{ 总模糊指数 } \\
\hline & $\begin{array}{c}\text { 建房前 } \\
/ \%\end{array}$ & $\begin{array}{c}\text { 建房后 } \\
1 \%\end{array}$ & $\begin{array}{c}\text { 建房前 } \\
1 \%\end{array}$ & $\begin{array}{c}\text { 建房后 } \\
1 \%\end{array}$ & $\begin{array}{c}\text { 建房前 } \\
1 \%\end{array}$ & $\begin{array}{c}\text { 建房后 } \\
1 \%\end{array}$ & $\begin{array}{c}\text { 建房前 } \\
1 \%\end{array}$ & $\begin{array}{c}\text { 建房后 } \\
1 \%\end{array}$ & $\begin{array}{c}\text { 建房前 } \\
\quad / \%\end{array}$ & $\begin{array}{c}\text { 建房后 } \\
\quad / \%\end{array}$ & $\begin{array}{c}\text { 建房前 } \\
\quad / \%\end{array}$ & $\begin{array}{c}\text { 建房后 } \\
1 \%\end{array}$ \\
\hline $0.000 \sim 0.100$ & 0.00 & 0.00 & 0.00 & 0.00 & 2.45 & 2.15 & 0.00 & 0.00 & 1.53 & 0.00 & 0.00 & 0.00 \\
\hline $0.101 \sim 0.200$ & 0.31 & 0.00 & 0.31 & 0.00 & 25.46 & 13.80 & 0.61 & 0.00 & 20.86 & 0.00 & 0.00 & 0.00 \\
\hline $0.201 \sim 0.300$ & 1.84 & 1.23 & 0.31 & 0.00 & 44.17 & 50.00 & 0.61 & 0.31 & 44.79 & 1.53 & 14.42 & 0.00 \\
\hline $0.301 \sim 0.400$ & 0.61 & 2.15 & 5.52 & 0.00 & 21.17 & 19.33 & 11.04 & 1.53 & 23.62 & 12.58 & 59.51 & 8.28 \\
\hline $0.401 \sim 0.500$ & 4.91 & 9.82 & 61.35 & 34.05 & 4.29 & 7.06 & 22.70 & 12.27 & 8.28 & 46.01 & 23.93 & 53.68 \\
\hline $0.501 \sim 0.600$ & 12.58 & 15.95 & 15.64 & 12.58 & 1.84 & 1.23 & 32.82 & 21.78 & 0.92 & 28.22 & 1.84 & 31.29 \\
\hline $0.601 \sim 0.700$ & 25.46 & 37.12 & 10.12 & 16.87 & 0.31 & 2.45 & 19.33 & 26.99 & 0.00 & 8.59 & 0.31 & 5.52 \\
\hline $0.701 \sim 0.800$ & 28.83 & 23.93 & 5.52 & 21.17 & 0.31 & 2.45 & 7.98 & 25.15 & 0.00 & 1.23 & 0.00 & 1.23 \\
\hline $0.801 \sim 0.900$ & 12.27 & 7.36 & 1.23 & 10.43 & 0.00 & 1.23 & 4.91 & 10.12 & 0.00 & 1.84 & 0.00 & 0.00 \\
\hline $0.901 \sim 1.000$ & 13.19 & 2.45 & 0.00 & 4.91 & 0.00 & 0.31 & 0.00 & 1.84 & 0.00 & 0.00 & 0.00 & 0.00 \\
\hline 汇总 & 100.00 & 100.00 & 100.00 & 100.00 & 100.00 & 100.00 & 100.00 & 100.00 & 100.00 & 100.00 & 100.00 & 100.00 \\
\hline 平均隶属度 & 0.71 & 0.65 & 0.52 & 0.64 & 0.26 & 0.29 & 0.56 & 0.66 & 0.27 & 0.49 & 0.36 & 0.49 \\
\hline
\end{tabular}

得改善。但在具体功能隶属度分布变化存在明显 差异,具体如下:

第一, 家庭经济隶属度处于 $(0.601,0.800]$ 之间 的农民工家庭在建房后扩大 $6.76 \%$, 但 0.600 以下的 却增加了 $8.90 \%, 0.800$ 以上的则减少了 $15.61 \%$ 。由 此可见, 回乡建房农民工家庭经济状况变差的比例 大于变好的比例。第二,建房前, $61.35 \%$ 的农民工家 庭发展机会与社会资本隶属度分布为 $(0.401,0.500]$, 相比建房后, $65.96 \%$ 的农民工家庭在该功能的隶属 度超过 0.500 , 其中, 分布在 $(0.701,0.800]$ 的家庭占 比达到 $21.17 \%$ 。第三, 从家庭保障功能看, 无论建 房前或建房后, 更大部分的农民工家庭隶属度都比 较低, 0.400 以下的家庭占比分别为 $93.25 \%$ 和 $85.28 \%$, 相对比较接近。第四, 家人心理情感功能 隶属度在回乡建房农民工家庭分布总体比较分散, 但建房后分布于较高隶属度的农民工家庭比例有 所增加。第五, 建房前, 超过 $2 / 3$ 的农民工家庭的住 房与居住环境功能隶属度在 0.400 以下, 说明大多 数家庭的住房与居住环境处于较低福利水平; 而建 房后则有了较明显变化, $74.23 \%$ 家庭隶属度在 0.400 以上。从以上数据对比可以看出, 回乡建房对 农民工家庭福利有正向的促进影响。

\section{2 按照转换因素对农民工家庭福利效应的分解}

如上所述, 本文确定外出农民工家庭所在的设
区市 $\left(T_{1}\right)$ 、所在村庄与乡镇政府距离 $\left(T_{2}\right)$ 、代际 $\left(T_{3}\right) 、$ 建房前外出人口占比 $\left(T_{4}\right)$ 作为农民工回乡建房家庭 福利的转换因素。下文考察这些因素在回乡建房 向农民工家庭福利的功能性活动转换过程中是发 挥促进还是阻碍作用。本文分析发现(表 5), 所在 的设区市 $\left(T_{1}\right)$ 为福州市, 村庄与乡镇政府距离 $\left(T_{2}\right)$ $2.1 \sim 3.0 \mathrm{~km}$, 代际 $\left(T_{3}\right)$ 为老一代农民工, 建房前外出 人口占比 $\left(T_{4}\right) 76 \% \sim 100 \%$, 农民工家庭是受回乡建 房影响最大的群体, 前后隶属度差值都超过了 0.100 , 分别为 $0.175 、 0.169 、 0.130$ 和 0.159 。此外, 除 了村庄与乡镇政府距离 $\left(T_{2}\right) 3.1 \sim 4.0 \mathrm{~km}$ 的农民工家 庭受回乡建房影响较小外(隶属度差值为 0.066 ), 其 他特征的农民工家庭回乡建房前后隶属度差值也 都超过 0.100 ,说明回乡建房对各类特征农民工家庭 总体福利起到促进作用。而从具体功能性活动指 标看,不同特征的农民工家庭其建房前后隶属度变 化存在较大差别,但没有表现出规律性差异。

\section{3 农民工回乡建房福利差异比较}

本部分利用问卷调查数据, 按照公式(6)计算, 得到回乡建房前农民工家庭福利差异系数为 0.18 , 而回乡建房后该差异系数变为 0.15 , 说明回乡建房 缩小了农民工家庭之间的福利差异, 缩小幅度为 $16.67 \%$ 。为了更简单形象反映福利差异，下文仿照 洛伦兹曲线的绘制方法绘制了农民工家庭福利的 


\section{表 5 不同转换因素下回乡建房农民工家庭福利变化的模糊评价}

Table 5 Fuzzy evaluation of family welfare changes of migrant workers returning thome to build houses under different conversion factors

\begin{tabular}{|c|c|c|c|c|c|c|c|c|c|c|c|c|c|}
\hline \multirow{2}{*}{\multicolumn{2}{|c|}{ 转换因素 }} & \multicolumn{2}{|c|}{$X_{1}$} & \multicolumn{2}{|c|}{$X_{2}$} & \multicolumn{2}{|c|}{$X_{3}$} & \multicolumn{2}{|c|}{$X_{4}$} & \multicolumn{2}{|c|}{$X_{5}$} & \multicolumn{2}{|c|}{ 加总 } \\
\hline & & 建房前 & 建房后 & 建房前 & 建房后 & 建房前 & 建房后 & 建房前 & $\begin{array}{l}\text { 建房后 } \\
\end{array}$ & 建房前 & 建房后 & 建房前 & 建房后 \\
\hline \multirow{3}{*}{$\begin{array}{l}T_{1} \\
\text { 设区市 }\end{array}$} & 南平市 & 0.671 & 0.565 & 0.512 & 0.569 & 0.259 & 0.281 & 0.544 & 0.575 & 0.283 & 0.514 & 0.363 & 0.463 \\
\hline & 福州市 & 0.693 & 0.591 & 0.490 & 0.672 & 0.309 & 0.392 & 0.586 & 0.700 & 0.227 & 0.499 & 0.360 & 0.535 \\
\hline & 漳州市 & 0.741 & 0.595 & 0.548 & 0.665 & 0.230 & 0.243 & 0.544 & 0.675 & 0.288 & 0.472 & 0.365 & 0.473 \\
\hline \multirow{6}{*}{$\begin{array}{l}T_{2} \\
\text { 村庄与乡镇 } \\
\text { 政府距离 }\end{array}$} & $\leqslant 1.0 \mathrm{~km}$ & 0.695 & 0.597 & 0.504 & 0.525 & 0.284 & 0.300 & 0.553 & 0.569 & 0.256 & 0.522 & 0.362 & 0.469 \\
\hline & $1.1 \sim 2.0 \mathrm{~km}$ & 0.711 & 0.623 & 0.550 & 0.658 & 0.256 & 0.316 & 0.572 & 0.670 & 0.275 & 0.495 & 0.371 & 0.506 \\
\hline & $2.1 \sim 3.0 \mathrm{~km}$ & 0.691 & 0.563 & 0.492 & 0.615 & 0.311 & 0.478 & 0.628 & 0.700 & 0.273 & 0.500 & 0.383 & 0.552 \\
\hline & $3.1 \sim 4.0 \mathrm{~km}$ & 0.687 & 0.579 & 0.533 & 0.616 & 0.319 & 0.304 & 0.562 & 0.558 & 0.345 & 0.508 & 0.411 & 0.477 \\
\hline & $4.1 \sim 5.0 \mathrm{~km}$ & 0.808 & 0.589 & 0.537 & 0.697 & 0.246 & 0.263 & 0.584 & 0.721 & 0.277 & 0.480 & 0.372 & 0.491 \\
\hline & $>5.0 \mathrm{~km}$ & 0.645 & 0.541 & 0.497 & 0.671 & 0.229 & 0.228 & 0.489 & 0.649 & 0.251 & 0.465 & 0.332 & 0.456 \\
\hline \multirow{2}{*}{$\begin{array}{l}T_{3} \\
\text { 代际 }\end{array}$} & 新生代农民工 & 0.722 & 0.630 & 0.521 & 0.649 & 0.261 & 0.281 & 0.542 & 0.641 & 0.299 & 0.504 & 0.373 & 0.484 \\
\hline & 老一代农民工 & 0.704 & 0.658 & 0.523 & 0.640 & 0.258 & 0.300 & 0.561 & 0.664 & 0.257 & 0.484 & 0.359 & 0.489 \\
\hline \multirow{4}{*}{$\begin{array}{l}T_{4} \\
\text { 建房前外出 } \\
\text { 人口占比 }\end{array}$} & $\leqslant 25 \%$ & 0.700 & 0.591 & 0.526 & 0.618 & 0.259 & 0.298 & 0.540 & 0.638 & 0.299 & 0.491 & 0.372 & 0.484 \\
\hline & $26 \% \sim 50 \%$ & 0.712 & 0.587 & 0.528 & 0.640 & 0.263 & 0.294 & 0.562 & 0.638 & 0.273 & 0.491 & 0.367 & 0.485 \\
\hline & $51 \% \sim 75 \%$ & 0.693 & 0.590 & 0.519 & 0.641 & 0.250 & 0.303 & 0.572 & 0.672 & 0.252 & 0.475 & 0.355 & 0.489 \\
\hline & $76 \% \sim 100 \%$ & 0.737 & 0.573 & 0.504 & 0.696 & 0.257 & 0.279 & 0.556 & 0.726 & 0.219 & 0.498 & 0.342 & 0.501 \\
\hline
\end{tabular}

“洛伦兹”曲线。首先, 按照福利指数由小到大将农 民工家庭进行有序排列, 所对应的纵坐标数值为农 民工家庭福利指数占全部农民工家庭福利指数总 值的比例, 横坐标则为该农民工家庭位次, 然后在 坐标上相应位置以点标示出来, 再用光滑曲线将各 点连接起来,分别做出回乡建房前后农民工家庭福 利的“洛伦兹”曲线。从图 1 可以看出,农民工回乡 建房前对应的曲线比回乡建房后的曲线,更向右下 角凸出, 表明回乡建房缩小了农民工家庭之间福利 差异。由此可以推论,受经济理性驱动, 只要建房 对其家庭福利改善是持续的,并且在城乡推拉格局 没有根本变化的情况下,农民工回乡建房可能仍将 继续。对于没有回乡建房的农民工家庭而言, 为了 不在同村人面前被拉开距离, 或将在未来回乡建 房。此外,在实施乡村振兴战略和宅基地“三权分 置”改革背景下, 农村宅基地和住房价值将愈发显 现，回乡建房对农民工家庭福利或将进一步改善， 未来可能有更多的农民工回乡建房。

\section{4 讨论}

第一, 以上研究发现回乡建房对农民工家庭福 利有正向的促进影响, 并在一定程度缩小了农民工 家庭之间的福利差异。这与 $\mathrm{Arif}^{\left[{ }^{6]}\right.}$ 的研究结论-
回乡建房没有使移民和他们的家庭受益, 却加大了 贫富差距一一有所不同。其中缘由为本文并非仅 从经济效应层面去解释,而是基于可行能力理论,从 经济、社会、心理等方面综合分析回乡建房为农民工 家庭所带来的变化,规避了传统福利理论仅用资源 或收人指标的单一局限性 ${ }^{[19]}$; 并摆脱 “标准投资模 式”难以解释移民家乡住房投资行为的困境 ${ }^{[8]}$ 。在 实践层面获得对近一半农民工回乡建房的社会现 象的客观理解, 即农民工回乡建房并非是一种为了 炫耀和攀比而发生的非理性行为 ${ }^{[38,39]}$ 。因此, 本文

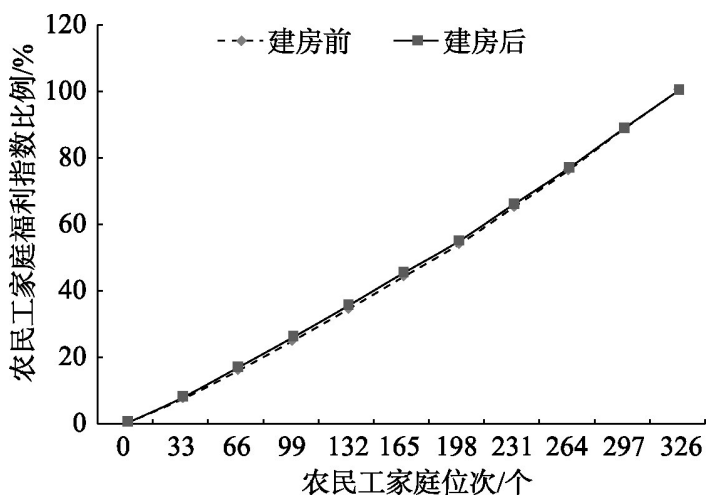

图 1 回乡建房前后农民工家庭福利的“洛伦兹”曲线 Figure 1 Lorentz curve of family welfare for migrant workers before and after housing construction 
会与社会资本、住房与居住环境等方面的福利都获

可视为一种新的研究尝试, 也提供了研究该领域一 个新的视角。

第二, 虽然阿玛蒂亚・森也主张应针对不同对 象选择不同的功能性活动指标体系, 在实证研究 中, 大多数学者也是根据研究主题和调查对象的特 征确定功能性活动指标的 ${ }^{[20-22]}$ 。但指标不同, 反映 福利内容就不同。国内外相关研究发现, 回乡建房 影响了移民在移居地 (流人地) 的住房消费 ${ }^{[0]}$, 居住 条件变差 ${ }^{[7]}$ 。因本文以家庭为分析单位研究农民工 回乡建房的家庭福利效应, 没有对建房后农民工个 人外出居住福利指标进行考察, 未来应需进一步探 讨。此外,一些指标的变化也许并不完全起因于农 民工回乡建房, 其中还可能是因为外部宏观的社会 经济因素改变。因此, 提出准确有效的功能性活动 指标体系对于准确测量农民工回乡建房家庭福利 效应尤为重要。

第三, 本文数据来源于福建省农民工流出地的 实地调查。但置于全国范围看, 东中西部地区的农 民工流出地情况差异较大, 而流出地情况是影响农 民工回乡建房的重要变量。福建省不是农民工流 出大省, 不能代表全国农民工整体的情况。因此, 还不足以将本文所获得结果推及全国。未来, 应增 加农民工外出及回乡建房的其他典型地区的调查, 以提高研究结论的普适性。

\section{5 结论与建议}

\section{1 结论}

居住是福利的重要组成部分, 也是其他福利保 障的基础。改善家庭福利是农民工回乡建房的行 为目标, 也是评价该行为的主要指标, 更是政府制 定政策的重要依据。本文基于阿玛蒂亚・森的可行 能力理论, 借鉴其他领域和主题有关农户家庭福利 的研究思路与方法, 构建回乡建房农民工家庭福利 的功能性活动指标, 利用在福建省农民工流出地的 问卷调查数据, 采用模糊数学综合评价方法, 分析 回乡建房前后农民工家庭福利变化; 借鉴洛伦兹系 数计算 “福利差异系数”, 反映回乡建房前后不同农 民工家庭福利差异, 得出以下主要结论:

(1) 回乡建房对农民工家庭福利有正向的促进 作用。其中, 家庭保障、家人心理情感、家庭发展机
得改善, 改善幅度渐次加大。但总体福利仍然低于 中等水平。

(2)部分农民工回乡建房后,居住成本、负债金 额等都有不同程度的增加,家庭经济自由度也有所下 降,导致家庭经济方面的福利变差。其中, 还存在部 分农民工家庭超限占地，超大建房等“过度投资”行 为。这不仅加大了农民工家庭经济负担,也造成大 量土地被占用、被虚耗,城乡资源配置效率降低, 总 体上不利于中国的城镇化进程和乡村振兴。

(3) 回乡建房在一定程度上缩小了农民工家庭 之间的福利差异, 以至于部分农民工为了不被同村人 拉开距离, 往往举全家之力, 毕其一生, 甚至不惜举 债以回乡建房。因此,不能以“自我”的价值观评价 近一半农民工这一“他者”的回乡建房行为, 并简单 地认为这是一种为了炫耀和攀比而发生的非理性行 为,其背后有着更为丰富而复杂的社会意涵。

\section{2 建议}

福利改善是人们行为选择的重要目标之一,也 是本文研究的实践意义所在。基于提高农民工家 庭福利的目标要求,得出如下几点建议:

第一,优化城乡区域产业结构和空间布局,通 过产业转移, 振兴农民工流出地的乡村产业, 帮助 农民工在家门口就业, 实现就地城镇化。由此, 部 分农民工可以住在农村自己的家中,直接化解农村 住房过剩和城市住房不足之间的矛盾，提高农民工 及其家人的实际居住福利。

第二, 改变长期以来农民建房几乎是独立于公 共政策管理体系之外、处于“自建自管自用自灭”的 境况, 加强农村建房引导与管理。严格实行农村 “一户一宅” 制度, 规范建房审批程序, 治理超高超 大违法违规建房; 开展移风易俗活动,倡导合理适 度的住房建设 ${ }^{[5]}$, 减轻农民因建房所造成的过高经 济负担。

第三,鼓励和支持各类返乡、下乡人员到农村租 赁利用外出农民工的闲置农房和宅基地, 发展分享 农场、共享农庄、创意农业、特色文化产业、乡村旅游 或乡村民宿业, 盘活闲置宅基地和住房资源, 增加 农民工的财产性收人,改善农民工家庭的经济福利。 


\section{参考文献(References):}

[1] 李海波, 尹华北. 住房消费对农民工城市融人的影响及其差异 研究: 基于 CGSS2013 数据分析[J]. 消费经济, 2018, 34(3): 4953. [Li H B, Yin H B. A study on the impacts of housing consumption on migrant workers' city integration and their differences: Based on the analysis of CGSS 2013[J]. Consumer Economics, 2018, 34(3): 49-53.]

[2] 仲济香, 张璋, 李晓玲, 等. 基于 “人地挂钩”的农民工住房问题 调查研究[J]. 中国国土资源经济, 2019, 32(1): 46-49. [Zhong J

X, Zhang Z, Li X L, et al. Issues with regard to the housing of migrant workers based on "man linking land"[J]. China Land and Resources Economics, 2019, 32(1): 46-49.]

[3] 明娟, 曾湘泉. 农村劳动力外出与家乡住房投资行为: 基于广 东省的调查 [J]. 中国人口科学, 2014, (4): 110-120. [Ming J, Zeng X Q. Migration and housing investment in rural China: Based on survey in Guangdong Province[J]. Chinese Journal of Population Science, 2014, (2): 110-120.]

[4] Sen A. Commodities and Capabilities[M]. Oxford: Oxford University Press, 1999.

[5] 杨国永, 管曦, 许文兴. 农民工回乡建房动机及其类型分析: 基 于福建省农民工流出地的调查[J]. 中国农业大学学报, 2018, 23(12): 232-248. [Yang G Y, Guan X, Xu W X. Analysis on motivation and category of migrant workers' returning hometown to build houses: Based on the investigation of the outflow of migrant workers in Fujian Province[J]. Journal of China Agricultural University, 2018, 23(12): 232-248.]

[6] Arif H. Migration, small towns and social transformations in Paki$\operatorname{stan[J].~Environment~and~Urbanization,~2010,~22(1):~33-50.~}$

[7] Hirsch J. A Courtship After Marriage: Sexuality and Love in Mexican Transnational Families[M]. Los Angeles: University of California Press, 2003.

[8] Osili U O. Migrants and housing investments: Theory and evidence from Nigeria[J]. Economic Development and Cultural Change, 2004, 52(4): 821-849.

[9] 董昕, 张翼. 农民工住房消费的影响因素分析[J]. 中国农村经 济, 2012, (10): 37-48. [Dong X, Zhang Y. Analysis of the factors affecting the housing consumption of migrant workers[J]. China Rural Economy, 2012, (10): 37-48.]

[10] 刘林平, 范长显, 朱艳婷. 住房的羁绊: 对农民工落户城市意愿 的一个关键影响因素的研究 [J]. 劳动社会学评论, 2015, (2): 45-52. [Liu L P, Fan C Y, Zhu Y T. The study of housing: A key influencing factor for migrant workers' willingness to settle in cities[J]. Labor Sociology Review, 2015, (2): 45-52.]

[11] 刘成斌, 周兵. 中国农民工购房选择研究[J]. 中国人口科学, 2013, (6): 100-108. [Liu C B, Zhou B. Research on house-pur- chase choice of China's peasant- workers[J]. Chinese Journal of Population Science. 2013, (6): 100-108.]

[12] 徐玲, 肖双喜. 农民工农村住房过剩与城市住房不足矛盾研究 [J]. 安徽农业大学学报(社会科学版), 2012, (4): 15-18. [Xu L, Xiao S X. On the contradiction between migrant workers' surplus of rural housing and shortage of urban housing[J]. Journal of Anhui Agricultural University(Social Science Edition), 2012, 21(4): 15-18.]

[13] 贾肖明, 洪奕宜, 陈祥蕉. 莫让进城农民变成“两只老鼠” [EB/ OL]. (2011-03-05) [2018-10-22]. http: //news.cntv.cn/20110305/ 104404.shtml. [Jia X M, Hong Y Y, Chen X J. Do Not Let the Farmers into "Two Mice”[EB/OL]. (2011-03-05) [2018-10-22]. http: //news.cntv.cn/20110305/104404.shtml.]

[14] 胡建坤, 田秀娟. 农民工回乡建房行为研究[J]. 农业经济问题, 2012, (12): 53-60. [Hu J K, Tian X J. An empirical study on behavior of migrant worker's going back to build farmhouses in China[J]. Issues in Agricultural Economy, 2012, (12): 53-60.]

[15] 王珊, 张安录, 张叶生. 农地城市流转的农户福利效应测度 [J]. 中国人口・资源与环境, 2014, 24(3): 108-115. [Wang S, Zhang A L, Zhang Y S. Measurement of household welfare change in the process of rural-urban land conversion[J]. The Population, Resource and Environment of China, 2014, 23(3): 108-115.]

[16] 徐烽烽, 李放, 唐炎. 苏南农户土地承包经营权置换城镇社会保 障前后福利变化的模糊评价: 基于森的可行能力视角 [J]. 中国 农村经济, 2010, (8): 67-79. [Xu F F, Li F, Tang Y. Fuzzy evaluation of welfare changes before and after the substitution of farmers right to contracted land management in southern Jiangsu: Based on Sen's feasible capacity perspective[J]. China's Rural Economy, 2010, (8): 67-79.]

[17] 高进云, 乔荣锋, 张安录. 农地城市流转前后农户福利变化的模 糊评价: 基于森的可行能力理论[J]. 管理世界, 2007, (6): 4555. [Gao J Y, Qiao R F, Zhang A L. Fuzzy evaluation of farmers' welfare changes before and after farmland conversion: Based on Sen's theory of feasible capability[J]. Management World, 2007, (6): 45-55.]

[18] 阿玛蒂亚・森. 以自由看待发展 $[\mathrm{M}]$. 北京: 中国人民大学出版 社, 2013. [Sen A. Development as Freedom[M]. Beijing: China Renmin University Press, 2013.]

[19] 成程, 陈利根. 经济发达地区集中居住农民福利水平影响因素 分析: 基于可行能力理论与结构方程模型[J]. 安徽农业大学学 报(社会科学版), 2014, 23(2): 1-9. [Cheng C, Chen L G. An analysis of factors influencing centralized living farmers' welfare in economically developed regions: Based on the theory of capability approach and SEM[J]. Journal of Anhui Agricultural University(Social Science Edition), 2014, 23(2): 1-9.]

[20] 贾燕, 李钢, 朱新华, 等. 农民集中居住前后福利状况变化研究: 基于森的“可行能力”视角[J]. 农业经济问题, 2009, (4): 92-96. [Jia Y, Li G, Zhu X H, et al. Research on the welfare change be- 
fore and after the farmers concentration of living: Based on Sen's "feasible capacity" perspective[J]. Issues in Agricultural Economy, 2009, (4): 92-96.]

[21] 伽红凯, 王树进. 集中居住前后农户的福利变化及其影响因素 分析: 基于对江苏省农户的调查[J]. 中国农村观察, 2014,(1): 26-39. [Jia H K, Wang S J. Analysis on the changes of farmers' welfare before and after concentrated residence and its influencing factors: Based on the survey of farmers in Jiangsu Province[J]. China Rural Observation, 2014, (1): 26-39.]

[22] 朱珊, 黄朝禧. 湖北鄂州和仙桃两地农民集中居住前后福利测度 与变化的实证研究 [J]. 生态与农村环境学报, 2014, 30(5): 674680. [Zhu S, Huang C X. Empirical research of measurement and variation of farmers' welfare before and after concentration of living (inhabitaregion): A case study of Ezhou and Xiantao in Hubei Province[J]. Journal of Ecology and Rural Environment, 2014, 30(5): 674-680.]

[23] 钟晓华. 可行能力视域下农民 “上楼”前后多维福利的追踪测度 [J]. 广东行政学院学报, 2015, 27(2): 93-100. [Zhong X H. Tracing the multidimensional welfare of farmers before and after going upstairs in the perspective of feasible capability[J]. Journal of Guangdong Institute of Administration, 2015, 27(2): 93-100.]

[24] Laderchi C R. Poverty and its many dimensions: The role of income as an indicator[J]. Oxford Development Studies, 1997, 25(3): 345-360.

[25] Brandolini A, D’ Alessio G. Measuring Well-Being in the Functioning Space[C]. Cracow: General Conference of the International Association for Research in Income and Wealth, 1998.

[26] Nussbaum M. Capabilities as fundamental entitlements: Sen and social justice[J]. Feminist Economics, 2003, 9(2-3): 33-59.

[27] 袁方, 史清华, 卓建伟. 农民工回流行为的一个新解释: 基于森 的可行能力理论[J]. 中国人力资源开发, 2015, (1): 87-96. [Yuan F, Shi Q H, Zhuo J W. A new explanation of return of migrant workers based on Sen's capability theory[J]. China Human Resources Development, 2015, (1): 87-96.]

[28] Frank R H. The demand for unobservable and other non-positional goods[J]. American Economic Review, 1985, 75(1): 101-116.

[29] 李燕琼, 魏玲丽. 中国城市化过程中土地征用与农民惜地心态 研究: 基于东、中、西部 1542 个失地农民的问卷调查 $[\mathrm{J}]$. 农村经 济, 2012, (5): 33-36. [Li Y Q, Wei L L. Study on land requisition and peasant's pity in China's urbanization process: Based on questionnaire survey of 1542 landless peasants in eastern, middle and western regions[J]. Rural Economy, 2012, (5): 33-36.]

[30] Robeyns I. Sen's capability approach and gender inequality: Selecting relevant capabilities[J]. Feminist Economics, 2003, 9(2-3): 61-92.

[31] 罗芳. 外来农民工家乡汇款的影响因素及动机分析: 以湖北省 武汉市为例[J]. 中国农村经济, 2007, (S1): 49-56. [Luo F. Influencing factors and motivations of remittances from migrant workers: A case study of Wuhan, Hubei[J]. China Rural Economy, 2007, (S1): 49-56.]

[32] 明娟. 外出农民工特征变量及行为抑制: 从汇款动机生发[J]. 改 革, 2011, (3): 82-88. [Ming J. The personal variables and behavior restraint of the rural migrant workers: Generated from the motivation of remittance[J]. Reform, 2011, (3): 82-88.]

[33] 明娟, 张建武. 回流意愿、居留时间与农民工汇款: 基于广东用 工企业的调查[J]. 农业经济问题, 2011, 32(3): 53-59. [Ming J, Zhang J W. Analysis on the impact of the intent to return and the length of stay on the rural migration's remittances: Based on the enterprise survey of Guangdong Province[J]. Issues in Agricultural Economy, 2011, 32(3): 53-59.]

[34] 杨纶标, 高英仪, 凌卫新. 模糊数学原理及应用 $[\mathrm{M}]$. 广州: 华南 理工大学出版社, 2006. [Yang L B, Gao Y Y, Ling W X. The Principle and Application of Fuzzy Mathematics[M]. Guangzhou: South China University of Technology Press, 2006.]

[35] Cerioli A, Zani S, A Fuzzy Approach to the Measurement of Poverty[A]. Dagum C, Zenga M. Income and Wealth Distribution, Inequality and Poverty[C]. Berlin: Spring-Verlag, 1990.

[36] Cheli B, Lemmi A. A 'totally' fuzzy and relative approach to the multidimensional analysis of poverty[J]. Economic Notes, 1995, 24 (1): 115-133.

[37] Stark O, Bloom D E. The new economics of labor migration[J]. The American Economic Review, 1985, 75(2): 173-178.

[38] 祝仲坤. 农民工返乡建房行为研究: 基于推拉理论的解释框架 [J]. 经济体制改革, 2017, (3): 89-94. [Zhu Z K. Migrant workers returning home to house: An interpretation framework based on push \& pull theory[J]. Reform of Economic System, 2017, (3): 89-94.]

[39] 梁彩花, 周金䀧, 张琼. 返乡农民工炫耀性消费行为的社会心理 分析[J]. 广西民族研究, 2010, (4): 170-174. [Liang C H , Zhou J Q, Zhang Q. Conspicuous consumption of migrant workers returning home social psychological analysis of behavior[J]. Guangxi Ethnic Studies, 2010, (4): 170-174.] 


\title{
Household welfare change of migrant workers returning home to build houses: \\ Based on a survey of migrant worker source areas in Fujian Province
}

\author{
YANG Guoyong ${ }^{1}$, JIANG Qiang ${ }^{2}$, TIAN Tian ${ }^{1}$, XU Wenxing ${ }^{3}$ \\ (1. College of Public Administration, Fujian Agriculture and Forestry University, Fuzhou 350002, China; \\ 2. College of Computer and Information, Fujian Agriculture and Forestry University, Fuzhou 350002, China; \\ 3. College of Management, Fujian Agriculture and Forestry University, Fuzhou 350002, China)
}

\begin{abstract}
Residence is an important part of welfare and the basis of overall well-being. Based on Amartya Sen's theory of feasible capability, this study constructed a welfare evaluation index system for migrant workers in rural areas. Using fuzzy mathematics comprehensive evaluation method and questionnaire survey data of migrant workers in Fujian Province, this study evaluated household welfare change of migrant workers who returned home to build houses. Lorentz coefficient was used to compare the differences in family welfare before and after returning to the countryside. The study found that returning home to build a house has a positive effect on the welfare of migrant workers' families and to some extent narrows the welfare difference between these families, but family welfare is still below the medium level and family economic situation gets worse. With the goal of improving the welfare of migrant workers' families, we should promote the urbanization of migrant workers on the spot and improve the actual living condition, strengthen the guidance and management of migrant workers returning to the countryside to build houses, advocate reasonable and moderate housing construction, alleviate the economic burden caused by housing construction, revitalize idle homesteads and housing resources, and increase property-related income of migrant workers. Comparing the welfare changes before and after the construction of a house can improve understanding of the impact of returning home to build a house on migrant workers' families and provide a basis for the government to formulate policies.
\end{abstract}

Key words: migrant workers; returning home to build houses; welfare; feasible capability; fuzzy mathematics; Lorentz coefficient; Fujian Province 